\title{
KINERJA GURU MATEMATIKA BERDASARKAN PERSEPSI DAN KOMPETENSI SISWA SMP DI KOTA MERAUKE
}

\author{
Khumaeroh Dwi Nur'aini, Maria Fransina Veronica Ruslau \\ Universitas Musamus, Merauke-Papua \\ Email: khumaeroh_fkip@unmus.ac.id
}

\begin{abstract}
Abstrak
Penelitian ini bertujuan untuk mengevaluasi kekurangan dan kelebihan guru dalam proses mengajar ditinjau dari aspek kompetensi guru matematika dan menggambarkan bagaimana keempat kompetensi guru tersebut telah berjalan dalam proses pembelajaran di kelas berdasarkan persepsi siswa dikaitkan dengan kompetensi siswa itu sendiri dengan menggunakan teknik analisis data Structural Equation Modeling (SEM). Populasi Penelitian ini adalah siswa SMP Di Kota Merauke, Papua. Teknik pemilihan sampel dengan menggunakan proportional random sampling yang dilakukan dengan simple random sampling sehingga diperoleh jumlah sampel sebanyak 436 siswa. Teknik pengumpulan data dilakukan dengan penyebaran angket persepsi siswa mengenai kinerja guru matematika yang terdiri dari 48 pertanyaan dalam bentuk skala Likert. Penelitian ini menyimpulkan bahwa kompetensi pedagogik dan sosial merupakan kompetensi yang mempengaruhi kompetensi siswa dengan kompetensi pedagogik guru matematika yang paling berpengaruh terhadap kompetensi siswa. Oleh sebab itu, untuk meningkatkan kompetensi siswa, guru-guru perlu meningkatkan kompetensi Pedagogik dan kompetensi Sosial.
\end{abstract}

Kata Kunci: Kompetensi Siswa, Pemodelan Persamaan Struktural, Kompetensi Guru

\begin{abstract}
This study aims to evaluate the strengths and weaknesses of teachers in the teaching process in terms of aspects of mathematics teacher competency. It describes how the four teacher competencies have been running in the learning process in the classroom based on students' perceptions related to student competencies themselves using Structural Equation Modeling data analysis techniques (SEM). The study population was all junior high school students in Merauke City, Papua. The method of sampling was used proportional random sampling, which is continued by simple random sampling, to obtain a total sample of 436 students. The data collection was carried out by distributing questionnaires to students' perceptions about the performance of mathematics teachers consisting of 48 questions in the form of a Likert scale. The results obtained that pedagogic and social competencies are competencies that affect student competencies with mathematics teacher pedagogical competence is most influential on student competencies. Therefore, to improve student competency, teachers need to improve pedagogical and social competence.
\end{abstract}

Keywords: Student Competency, Structural Equation Modeling, Teacher Competency

\section{PENDAHULUAN}

Meningkatkan prestasi dan memberikan pengalaman belajar yang berkualitas bagi semua siswa telah lama menjadi hasil terpenting yang diharapkan dari sekolah. Kualitas 
guru menjadi salah satu faktor yang paling penting yang dapat mempengaruhi prestasi siswa. Dalam Peraturan Pemerintah Republik Indonesia Nomor 19 Tahun 2017 tentang Guru, dijelaskan bahwa standar kompetensi guru didasari atas 4 kompetensi utama yaitu kompetensi pedagogik, kompetensi kepribadian, kompetensi sosial dan kompetensi profesional. Selanjutnya, performa guru merupakan kemampuan guru untuk memberikan keterampilan yang relevan, pengetahuan menggunakan metode yang sesuai secara konsisten dari waktu ke waktu untuk meningkatkan pembelajaran dan prestasi siswa (Bashir, Alias, Moh, \& Halizah, 2017).

Guru dapat diartikan sebagai figur seorang pemimpin dan teladan bagi siswanya di sekolah. Penelitian yang dilakukan oleh Hattie (2003), Rowe dan Rowe (2003), serta Kuriakides, Christoforou, dan Charalambous (2013), menunjukkan bahwa guru memberikan pengaruh yang paling penting pada kinerja akademik siswa. Oleh karena itu, sering kali kegagalan siswa dalam belajar dikaitkan dengan kinerja guru dalam mengajar.

Di lain pihak, minat siswa atau lebih khusus pada perasaan/persepsi siswa dalam mengikuti pembelajaran juga merupakan salah satu faktor yang dapat mempengaruhi hasil belajar siswa. Allport (dalam Bashir dkk., 2017) menggambarkan persepsi sebagai cara orang menilai orang lain dengan siapa mereka berhubungan. Sejalan dengan pendapat tersebut, Slameto (dalam Tarmiji, Basyah, \& Yunus, 2016) menyatakan bahwa, melalui persepsi manusia terus mengadakan hubungan dengan lingkungannya melalui inderanya yang kemudian meringkas informasi yang diperoleh sehingga dapat memberikan tanggapan mengenai baik buruknya informasi tersebut.

Lebih lanjut, penguasaan kompetensi guru akan dapat terlihat ketika proses pembelajaran yaitu pada saat guru berinteraksi dengan siswa (Danim, 2010). Secara umum, siswa biasanya menilai guru mereka dari beberapa aspek seperti pengetahuan guru tentang materi pelajaran, kemampuan komunikasi, pilihan metode pengajaran yang sesuai dan keterampilan manajemen kelas. Peran siswa dalam proses pengajaran sangat penting karena persepsi mereka dapat mempengaruhi sikap mereka terhadap mata pelajaran tersebut. Sehingga penilaian siswa terhadap kinerja guru jelas tidak boleh diabaikan, persepsi siswa terhadap kinerja guru dapat menjadi sumber informasi yang bagus, karena siswalah yang mengalami, mengamati dan merasakan proses pembelajaran di kelas dan evaluasi mereka akan membantu untuk menentukan apakah guru telah melakukan pembelajaran dengan baik dan sesuai standar atau belum. Sehingga siswa akan membuat 
penilaian yang lebih akurat tentang kinerja guru yang kemudian akan tercipta sistem evaluasi yang adil dan obyektif serta dapat membantu guru untuk merefleksikan dan menyesuaikan strategi mengajarnya untuk meningkatkan pemahaman dan prestasi siswa.

Kompetensi guru dan persepsi siswa keduanya saling berkaitan. Penguasaan kompetensi guru dengan baik akan menghasilkan pembelajaran yang baik pula dan pada akhirnya akan berpengaruh terhadap baiknya persepsi siswa (Nuryovi, Wiharna, \& Sriyono, 2017). Khususnya pada mata pelajaran matematika yang sering kali mendapatkan persepsi buruk dari sudut pandang siswa. Sebagian siswa menganggap mata pelajaran matematika merupakan mata pelajaran yang membosankan, sulit dan cukup menakutkan karena memiliki banyak perhitungan serta rumus-rumus sehingga memerlukan bakat intelektual khusus. Padahal matematika merupakan salah satu mata pelajaran yang menjadi dasar ilmu-ilmu lain dan selalu di pelajari mulai tingkat pendidikan dasar hingga pendidikan tinggi (Palobo \& Nur'aini, 2018). Pada penelitian Etuk, Afangideh, dan Uya (Etuk, Afangideh, \& Uya, 2013) menyatakan bahwa "when the students' perception of their teachers' characteristics is low, students' attitude towards mathematics tends to be negative". Artinya saat persepsi siswa terhadap karakteristik guru adalah rendah, maka sikap siswa terhadap matematika cenderung negatif. Kondisi ini dapat memengaruhi hasil belajar matematika siswa dan tidak sesuai dengan tujuan pembelajaran. Hal tersebut juga akan membuat guru terus dikritik karena karakteristik guru yang buruk dan kurangnya kualifikasi profesional yang diperlukan dalam mengajar. Penilaian siswa terhadap pengajaran yang dilakukan oleh guru merupakan salah satu bentuk evaluasi pembelajaran dan keefektifan yang dilakukan oleh guru (Ampadu, 2012; Brok, Brekelmans, \& Wubbels, 2006). Bagaimanapun juga evaluasi harus mempertimbangkan kebutuhan siswa dibanding hal lainnya (Sianturi \& Lin, 2016).

Tujuan dari penelitian ini adalah untuk mengevaluasi kekurangan dan kelebihan guru dalam proses mengajar ditinjau dari aspek kompetensi guru matematika dan menggambarkan bagaimana keempat kompetensi guru tersebut telah berjalan dalam proses pembelajaran di kelas berdasarkan persepsi siswa yang kemudian dikaitkan dengan kompetensi siswa itu sendiri. Kompetensi siswa dalam penelitian ini didasarkan pada ranah hasil belajar oleh Taksonomi Bloom. 


\section{METODE PENELITIAN}

Penelitian ini merupakan jenis penelitian kuantitatif. Subyek dari penelitian adalah siswa SMP Di Kota Merauke Tahun Ajaran 2018/2019 dengan jumlah sampel sebanyak 436 siswa. Instrumen yang digunakan berupa angket yang berisi indikator-indikator persepsi siswa mengenai kompetensi pedagogik, kepribadian, sosial dan kompetensi profesional guru serta kompetensi siswa. Terdapat 46 indikator yang digunakan dalam penelitian ini, yang terdiri dari 32 indikator untuk mengukur kompetensi guru dan 14 indikator untuk mengukur kompetensi siswa (Lampiran 1).

Teknik pengumpulan data dilakukan dengan menyebarkan angket persepsi siswa mengenai kinerja guru matematika. Data yang diperoleh dianalisis dengan menggunakan Program Komputer AMOS. Model estimasi standard AMOS menggunakan estimasi Maksimum Likelihood (ML). Estimasi ML menghendaki terpenuhinya asumsi:

- Sampel yang digunakan berukuran besar

Jumlah sampel yang digunakan dalam penelitian ini adalah 436 sampel, jumlah tersebut dapat dikategorikan ke dalam sampel besar. Menurut Tanujaya (2016), jumlah sampel yang digunakan sebaiknya lebih besar dari kali jumlah indicator yang digunakan untuk menyusun suatu instrument, dengan jumlah minimal sebanyak 200 reponden.

- Data berdistribusi normal multivariat

Uji normalitas ini dievaluasi dengan menggunakan nilai Critical Ratio (CR) dari skewness dan kurtosisnya. Jika nilai CR yang diperoleh berada pada rentang - 2.58 sampai dengan $2.58( \pm 2.58)$ pada tingkat singnifikansi $1 \%(0.01)$, maka dapat disimpulkan bahwa bahwa data yang digunakan berdistribusi normal baik univariate maupun multivariat.

- Model yang dihipotesiskan valid

Model yang dihipotesiskan telah didasari pada teori yang ada. Didukung dengan nilai validitas pada output yang disajikan pada tabel standardized regression weight, dan diperoleh hasil bahwa tidak ada variabel dengan nilai di bawah 0.5 , sehingga variabelvariabel bentukan yang disajikan pada model tersebut sudah dapat memenuhi asumsi valid. 


\section{HASIL DAN PEMBAHASAN}

Hasil uji Normalitas dengan menggunakan software AMOS versi 23 diperoleh nilai CR sebesar 2,526, sehingga dapat disimpulkan bahwa data telah memenuhi asumsi normal multivariat (Lampiran 2). Analisis kemudian dilanjutkan dengan mengamati nilai Loading Faktor. Berdasarkan output model awal, masih ditemukan beberapa indikator (variabel) yang memiliki nilai loading factor $<0,5$, sehingga indikator tersebut akan dihapus/dibuang dari data.

Lebih lanjut data dianalisis kembali dan diperoleh hasil Model ke-2 pada Gambar 1. Berdasarkan hasil pada Gambar 1 terlihat bahwa sudah tidak lagi ditemukan nilai loading factor yang $<0,5$, sehingga dapat disimpulkan bahwa indikator-indikator yang digunakan dalam penelitian sudah valid.

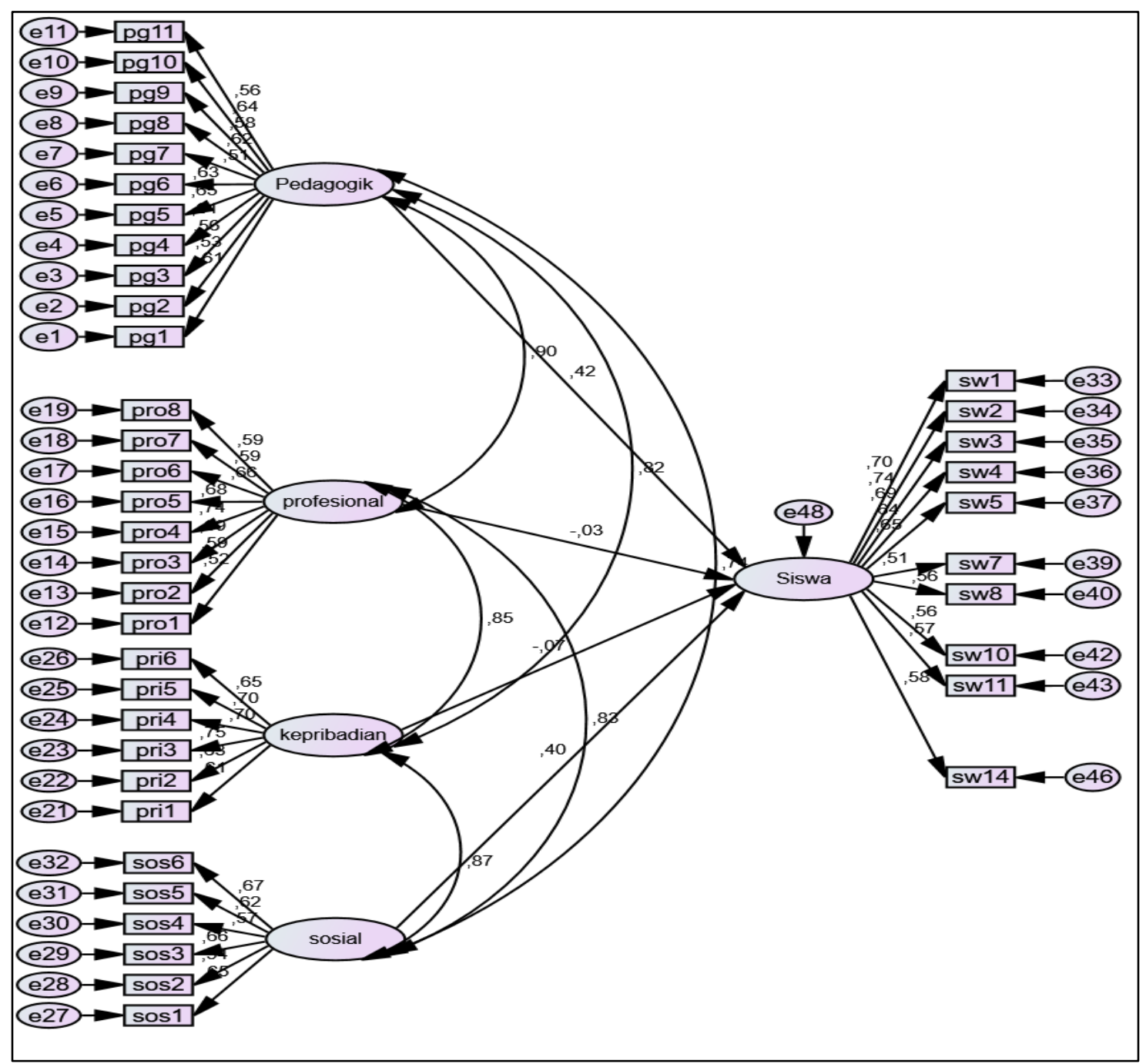

Gambar 1. Model Akhir Kinerja Guru Matematika Berdasarkan Persepsi Siswa 
Berdasarkan hasil analisis data, diperoleh hubungan yang terjadi antara variabel laten endogen Kompetensi Siswa dan variabel laten eksogen Kompetensi Pedagogik, Kompetensi Kepribadian, Kompetensi Sosial dan Kompetensi Profesional Guru Matematika SMP Di Kota Merauke adalah sebagai berikut:

a) Model Struktural

Secara Umum, model struktural yang dihasilkan adalah:

$Y=0,422 x_{1}-0,035 x_{2}-0,066 x_{3}+0,403 x_{4}$

dimana:

$\mathrm{Y}=$ Kompetensi Siswa

$x_{1}=$ Kompetensi Pedagogik

$x_{2}=$ Kompetensi Profesional

$x_{3}=$ Kompetensi Kepribadian

$x_{4}=$ Kompetensi Sosial

Berdasarkan Persamaan (1), tampak bahwa koefisien regresi hubungan antara variabel Kompetensi Siswa dengan Kompetensi Pedagogik dan Kompetensi Sosial bernilai positif, sedangkan dua variabel lainnya bernilai negatif. Hal tersebut mengindikasikan bahwa peningkatan kompetensi siswa hanya dipengaruhi oleh kompetensi pedagogik dan kompetensi sosial guru matematika. Persamaan tersebut juga menunjukkan koefisien regresi yang terbesar adalah koefisien regresi kompetensi pedagogik sehingga kompetensi pedagogik guru merupakan variabel yang paling berpengaruh terhadap kompetensi siswa.

b) Hubungan antara Variabel Laten dan Indikator

Secara Khusus, hubungan antara variabel laten eksogen dengan masing-masing indikatornya disajikan pada Tabel 1, yang mana tampak bahwa masing-masing koefisien bobot regresi variabel laten eksogen dengan masing-masing indikatornya bernilai positif. Sebagai contoh, pada variabel kompetensi pedagogik, koefisien bobot regresi indikator Pg5 adalah yang paling besar dan indikator Pg7 adalah yang paling kecil. Nilai yang dihasilkan tersebut mengindikasikan bahwa menurut siswa, guru telah menyampaikan kompetensi inti, kompetensi dasar dan indikator secara singkat dan jelas di awal pembelajaran dengan sangat baik, sedangkan untuk meningkatkan kompetensi siswa, 
pada variabel kompetensi pedagogik, Guru perlu memperhatikan kejelasan dalam menyampaikan tujuan pembelajaran, materi dan jawaban terhadap pertanyaan di kelas.

Tabel 1. Nilai Estimasi Bobot Regresi dari Variabel Endogen dan Eksogen pada setiap Indikator.

\begin{tabular}{cccccccccc}
\hline Var. & $\begin{array}{l}\text { Koef. } \\
\text { Jalur }\end{array}$ & Var. & $\begin{array}{l}\text { Koef. } \\
\text { Jalur }\end{array}$ & Var. & $\begin{array}{l}\text { Koef. } \\
\text { Jalur }\end{array}$ & Var. & $\begin{array}{l}\text { Koef. } \\
\text { Jalur }\end{array}$ & Var & $\begin{array}{l}\text { Koef. } \\
\text { Jalur }\end{array}$ \\
\hline Pg1 & 0,614 & Pro1 & 0,522 & Pri1 & 0,609 & Sos1 & 0,654 & Sw1 & 0,701 \\
Pg2 & 0,530 & Pro2 & 0,593 & Pri2 & 0,629 & Sos2 & 0,541 & Sw2 & 0,740 \\
Pg3 & 0,557 & Pro3 & 0,694 & Pri3 & 0,747 & Sos3 & 0,660 & Sw3 & 0,694 \\
Pg4 & 0,609 & Pro4 & 0,743 & Pri4 & 0,704 & Sos4 & 0,566 & Sw4 & 0,639 \\
Pg5 & 0,654 & Pro5 & 0,680 & Pri5 & 0,703 & Sos5 & 0,624 & Sw5 & 0,648 \\
Pg6 & 0,635 & Pro6 & 0,661 & Pri6 & 0,645 & Sos6 & 0,672 & Sw7 & 0,510 \\
Pg7 & 0,508 & Pro7 & 0,590 & & & & & Sw8 & 0,560 \\
Pg8 & 0,620 & Pro8 & 0,593 & & & & & Sw10 & 0,562 \\
Pg9 & 0,576 & & & & & & & Sw11 & 0,568 \\
Pg10 & 0,639 & & & & & & & Sw14 & 0,577 \\
Pg11 & 0,561 & & & & & & & & \\
\hline
\end{tabular}

Hasil tersebut bersesuaian dengan hasil penelitian Etuk dkk. (2003) yang menyatakan bahwa 98\% siswa sangat bergantung pada pengetahuan dari materi pembelajaran yang disampaikan oleh guru. Oleh karena itu, sangat penting bagi guru untuk fokus pada rencana pembelajaran (RPP) yang telah disusun sebelumnya (Sianturi, Chiang, \& Hurit, 2018), walaupun secara umum pada pelaksanaan kurikulum 2013, guru masih menghadapi beberapa kesulitan (Palobo dkk., 2018).

Pada variabel kompetensi profesional, koefisien bobot regresi indikator Pro4 adalah yang paling besar dan indikator Prol adalah yang paling kecil. Hasil tersebut mengindikasikan bahwa menurut siswa, kemampuan guru dalam menjelaskan pokok bahasan/topik secara sistematis dalam proses pembelajaran sudah sangat baik, sedangkan untuk meningkatkan kompetensi siswa, pada variabel kompetensi professional, Guru perlu memperhatikan ketepatan waktu kehadiran guru, sehingga proses pembelajaran menjadi lebih teratur, efisien dan materi yang dibahas sesuai dengan tujuan pembelajaran.

Selanjutnya pada variabel kompetensi Kepribadian, koefisien bobot regresi indikator Pri3 adalah yang paling besar dan indikator Pri1 adalah yang paling kecil. Hasil tersebut mengindikasikan bahwa menurut siswa, kearifan guru dalam mengambil keputusan (menyelesaikan persoalan siswa) sudah bagus. Namun, Guru hendaknya perlu memperhatikan rasa percaya diri akan kemampuan mengajar guru sehingga ketika rasa 
percaya diri guru dalam mengajar tinggi, maka guru akan dapat menjelaskan materi pembelajaran dengan lebih baik.

Pada variabel kompetensi sosial, koefisien bobot regresi indikator Sos6 adalah yang paling besar dan indikator Sos2 adalah yang paling kecil. Hasil tersebut mengindikasikan bahwa menurut siswa, Guru telah secara adil dalam memperlakukan siswa. Namun, Guru perlu meningkatkan kesediaan untuk meluangkan waktu untuk melakukan konsultasi diluar kelas karena adakalanya siswa belum cukup paham pada apa yang telah di pelajari di dalam kelas atau bisa jadi siswa merasa malu dan takut untuk bertanya ketika pembelajaran berlangsung.

Terakhir pada variabel kompetensi siswa, koefisien bobot regresi indikator Sw2 adalah yang paling besar dan indikator Sw7 adalah yang paling kecil. Hasil tersebut mengindikasikan bahwa pengetahuan siswa terhadap aplikasi dari setiap materi yang diajarkan oleh guru dalam kehidupan sehari-hari sudah sangat baik. Namun, siswa kurang memperhatikan ketika guru sedang menjelaskan di kelas sehingga untuk meningkatkan kompetensi siswa, siswa harus lebih memperhatikan ketika guru sedang menjelaskan di kelas.

Berdasarkan uraian di atas, persepsi siswa tentang kinerja guru matematika mereka sudah cukup bagus. Hal ini merupakan temuan penting karena menyediakan data empiris mengenai performa mengajar guru yang tercermin dalam keadaan saat ini. Guru sebagai manajer pendidikan dan pembuat kebijakan juga harus memperhatikan ketika persepsi siswa mengenai kinerja guru mereka rendah, karena dapat menimbulkan sikap negatif siswa, baik terhadap guru maupun terhadap mata pelajaran matematika. Seiring dengan meningkatnya sikap siswa, komitmen dan minat siswa terhadap performa mengajar guru matematika dan mata pelajaran matematika akan mengarah pada peningkatan prestasi.

\section{SIMPULAN}

Kompetensi Pedagogik dan kompetensi Sosial guru mempunyai hubungan yang positif dengan peningkatan kompetensi siswa. Kompetensi guru yang paling berpengaruh terhadap kompetensi siswa adalah kompetensi Pedagogik guru. Indikator guru menyampaikan kompetensi Inti, Kompetensi Dasar dan Indikator secara singkat dan jelas di awal pembelajaran adalah yang paling berpengaruh pada variabel kompetensi Pedagogik. Indikator Kemampuan guru dalam menjelaskan pokok bahasan/topik secara 
sistematis dalam proses pembelajaran adalah yang paling berpengaruh pada variabel kompetensi profesional. Selanjutnya, indikator Kearifan guru dalam mengambil keputusan menyelesaikan persoalan siswa adalah yang paling berpengaruh pada variabel kompetensi kepribadian dan indikator adil dalam memperlakukan siswa adalah yang paling berpengaruh pada variabel kompetensi sosial. Pada kompetensi siswa, pengetahuan siswa terhadap aplikasi dari setiap materi yang diajarkan oleh guru dalam kehidupan sehari-hari sudah sangat baik.

\section{DAFTAR PUSTAKA}

Ampadu, E. (2012). Students' Perceptions of their Teachers' Teaching of Mathematics: The Case of Ghana, International Online Journal of Educational Sciences, 4(2), 351-358.

Bashir, H., Alias, M., Moh, K., \& Halizah, A. (2017). Students 'Perceptions of Their Teachers' Performance in Teaching Engineering Drawing in Nigerian Tertiary Institutions, 3(10), 3001-3012.

Brok, P. Den, Brekelmans, M., \& Wubbels, T. (2006). Multilevel issues in research using students ' perceptions of learning environments : The case of the Questionnaire on Teacher Interaction. Learning Enviro Res, (2006), 199-213.

Danim, S. (2010). Profesionalisme dan Etika Profesi Guru. Bandung: Alfabeta.

Etuk, E. N., Afangideh, M. E., \& Uya, A. O. (2013). Students 'Perception of Teachers ' Characteristics and Their Attitude towards Mathematics in Oron Education Zone, Nigeria, 6(2), 197-204.

Hattie, J. (2003). Teachers Make a Difference, What is the research evidence?

Indonesia, R. (2017). Peraturan Pemerintah Republik Indonesia Nomor 19 Tentang Perubahan atas Peraturan Pemerintah Nomor 74 Tahun 2008 Tentang Guru.

Kyriakides, L., Christoforou, C., \& Charalambous, C. Y. (2013). What matters for student learning outcomes: A meta-analysis of studies exploring factors of effective teaching. Teaching and Teacher Education, 36, 143-152.

Nuryovi, Wiharna, O., \& Sriyono. (2017). Persepsi siswa tentang kompetensi pedagogik dan kompetensi kepribadian guru. Journal of Mechanical Engineering Education, 4(2), 219-224.

Palobo, M., \& Nur'aini, K. D. (2018). Pengembangan Perangkat Pembelajaran Berbasis Problem Based Learning Berorientasi pada Pengingkatan Kemampuan Penalaran dan Sikap Siswa Terhadap Matematika, Magistra, 5, 15-29.

Palobo, M., Sianturi, M., Marlissa, I., Purwanty, R., Dadi, O., \& Saparuddin, A. (2018). Analysis of Teachers' Difficulties on Developing Curriculum 2013 Lesson Plans, 226 (Icss), 1319-1324.

Rowe, K., \& Rowe, K. (2003). The Importance of Teacher Quality As A Key Determinant of Students 'Experiences and Outcomes of Schooling students 'experiences and outcomes of schooling. 
Sianturi, M., Chiang, C., \& Hurit, A. A. (2018). Impact of a Place-Based Education Curriculum on Indigenous Teacher and Students, International Journal of education, 11(1), 311-328.

Sianturi, M., \& Lin, H. H. (2016). Effects of Student's Grade to Teacher's Teaching: a Case Study in an Indigenous Classroom. Journal of Education and Vocational Research, 7(4), 6-11.

Tanujaya, B. (2016). Development of an Instrument to Measure Higher Order Thinking Skills in Senior High School Mathematics Instruction, Journal of Education and Practice, 7 (21), 144 - 148.

Tarmiji, Basyah, M. N., \& Yunus, M. (2016). Persepsi Siswa Terhadap Kesiapan Guru dalam Proses Pembelajaran. Jurnal Ilmiah Mahasiswa Pendidikan Kewarganegaraan Unsyiah, 1(1), 41-48. 
Lampiran 1. Daftar Simbol dan Indikator Penilaian Kompetensi Guru dan Siswa

\begin{tabular}{|c|c|}
\hline \multicolumn{2}{|r|}{ Kompetensi Pedagogik } \\
\hline Pg1 & Kesiapan memberikan pelajaran dan atau praktik \\
\hline Pg2 & $\begin{array}{l}\text { Upaya membangkitkan minat siswa pada mata pembelajaran ini di awal } \\
\text { pembelajaran (Apersepsi) }\end{array}$ \\
\hline Pg3 & Kemampuan menghidupkan suasana kelas \\
\hline Pg4 & $\begin{array}{l}\text { Guru menyampaikan kompetensi Inti, Kompetensi Dasar dan Indikator } \\
\text { secara singkat dan jelas di awal pembelajaran }\end{array}$ \\
\hline Pg5 & $\begin{array}{l}\text { Materi, tugas dan ujian yang diberikan sesuai dengan kompetensi inti dan } \\
\text { indikator yang ditetapkan }\end{array}$ \\
\hline Pg6 & $\begin{array}{l}\text { Kejelasan penyampaian tujuan pembelajaran, materi dan jawaban terhadap } \\
\text { pertanyaan di kelas }\end{array}$ \\
\hline Pg7 & Waktu khusus yang disediakan untuk berdiskusi tentang materi pelajaran \\
\hline Pg8 & Kemampuan mengarahkan diskusi sehingga mencapai sasaran \\
\hline Pg9 & Pemberian tugas terstruktur (rangkuman, latihan soal/pemecahan masalah, \\
\hline Pg10 & Pemberian umpan balik terhadap tugas (pengembalian tugas) \\
\hline g11 & $\begin{array}{l}\text { Materi, tugas dan ujian yang diberikan sesuai dengan yang diberikan } \\
\text { selama pembelajaran }\end{array}$ \\
\hline
\end{tabular}

\section{Kompetensi Profesional}

\begin{tabular}{ll}
\hline Pro1 & Ketepatan waktu kehadiran guru \\
\hline Pro2 & Penguasaan terhadap materi pelajaran \\
\hline Pro3 & Kemampuan menjelaskan pokok bahasan/topik secara sistematis \\
\hline Pro4 & Kemampuan memberi contoh relevan dari konsep yang diajarkan \\
\hline Pro5 & Kedalaman dan keluasan dalam membahas contoh kasus \\
\hline Pro6 & $\begin{array}{l}\text { Kemampuan menjelaskan keterkaitan bidang/topik yang diajarkan dengan } \\
\text { bidang/topik lain }\end{array}$ \\
\hline Pro7 & $\begin{array}{l}\text { Kemampuan menjelaskan keterkaitan bidang/topik yang diajarkan dengan } \\
\text { konteks kehidupan }\end{array}$ \\
\hline Pro8 & $\begin{array}{l}\text { Keragaman metode pembelajaran } \\
\text { penemuan terbimbing, pemecahan masalah) }\end{array}$ \\
\hline Pro9 & Pemanfaatan media dan teknologi pembelajaran \\
\hline Pri1 & Rasa percaya diri akan kemampuan mengajar \\
\hline Pri2 & Kewibawaan sebagai pribadi guru \\
\hline Pri3 & Kearifan dalam mengambil keputusan (menyelesaikan persoalan siswa) \\
\hline Pri4 & \begin{tabular}{l} 
Menjadi contoh dalam bersikap dan berperilaku \\
\hline
\end{tabular} \\
\hline
\end{tabular}




\begin{tabular}{ll} 
Pri5 & Kemampuan mengendalikan diri dalam berbagai situasi \\
\hline Pri6 & Adil dalam memperlakukan siswa \\
\hline \multicolumn{2}{c}{ Kompetensi Sosial } \\
\hline
\end{tabular}

Sos1 Kemampuan menerima kritik, saran, dan pendapat orang lain

Sos2 Kesediaan meluangkan waktu untuk konsultasi di luar kelas

Sos3 Mengenal dengan baik siswa yang mengikuti pembelajarannya

\begin{tabular}{ll}
\hline Sos4 & Mudah bergaul dengan segenap civitas (termasuk dengan siswa) \\
\hline Sos5 & Toleransi terhadap keberagaman siswa \\
\hline Sos6 & Adil dalam memperlakukan siswa \\
\hline & \multicolumn{2}{c}{ Kompetensi Siswa } \\
\hline
\end{tabular}

Sw1 Saya memahami konsep-konsep dasar dan materi matematika yang diajarkan oleh guru

Sw2 Saya mengetahui aplikasi dari setiap materi matematika yang diajarkan oleh guru dalam kehidupan sehari-hari

\begin{tabular}{ll}
\hline Sw3 & $\begin{array}{l}\text { Saya dapat menjelaskan kembali materi yang diajarkan oleh guru kepada } \\
\text { teman9 }\end{array}$ \\
\hline Sw4 & $\begin{array}{l}\text { Saya dapat memanfaatkan pengetahuan matematika saya dalam } \\
\text { menyelesaikan masalah sehari-hari }\end{array}$ \\
\hline Sw5 & $\begin{array}{l}\text { Saya dapat menghubungkan materi yang satu dengan lainnya sesuai dengan } \\
\text { kebutuhan }\end{array}$ \\
\hline
\end{tabular}

Sw6 Saya selalu hadir pada setiap jam pelajaran matematika

Sw7 Saya selalu memperhatikan ketika guru menjelaskan

Sw8 Saya selalu bertanya kepada guru jika ada materi yang belum saya pahami

\begin{tabular}{ll}
\hline Sw9 & Saya selalu aktif menjawab pertanyaan yang diajukan oleh guru \\
\hline Sw10 & $\begin{array}{l}\text { Saya selalu mendiskusikan hal-hal yang berkaitan dengan materi yang } \\
\text { diajarkan dengan teman }\end{array}$ \\
\hline Sw11 & $\begin{array}{l}\text { Saya berani mengungkapkan pendapat, baik dalam diskusi dikelas dengan } \\
\text { teman maupun guru }\end{array}$ \\
\hline Sw12 & $\begin{array}{l}\text { Saya mampu mempertahankan pendapat/hasil kerja sesuai apa yang saya } \\
\text { pahami }\end{array}$ \\
\hline
\end{tabular}

Sw13 Saya selalu menerima kritik dan saran yang membangun

Sw14 Setelah mengikuti pelajaran, kemampuan matematika saya meningkat 
Lampiran 2. Tabel Penilaian Uji Normalitas

\begin{tabular}{|c|c|c|c|c|c|c|}
\hline Variabel & Min & $\operatorname{Max}$ & Skew & c.r. & Kurtosis & c.r. \\
\hline Sw14 & 1,000 & 5,000 & $-2,468$ & $-1,986$ & $-3,254$ & $-1,083$ \\
\hline Sw11 & 1,000 & 5,000 & $-3,245$ & $-2,088$ & $-3,390$ & $-1,663$ \\
\hline Sw10 & 1,000 & 5,000 & $-3,651$ & $-1,552$ & 3,270 & 1,153 \\
\hline Sw8 & 1,000 & 5,000 & $-2,343$ & $-1,926$ & $-3,578$ & $-2,464$ \\
\hline Sw7 & 1,000 & 5,000 & $-2,770$ & $-1,568$ & 3,404 & 1,721 \\
\hline Sw5 & 1,000 & 5,000 & $-3,259$ & $-2,210$ & $-3,012$ & $-1,049$ \\
\hline Sw4 & 1,000 & 5,000 & $-2,623$ & $-2,310$ & 2,449 & 1,916 \\
\hline Sw3 & 1,000 & 5,000 & $-3,368$ & $-2,138$ & $-2,046$ & $-1,197$ \\
\hline Sw2 & 1,000 & 5,000 & $-2,391$ & $-2,335$ & $-2,114$ & $-1,487$ \\
\hline Sw1 & 1,000 & 5,000 & $-3,486$ & $-2,146$ & $-3,175$ & $-0,744$ \\
\hline Sos6 & 1,000 & 5,000 & $-3,328$ & $-1,319$ & 3,360 & 1,795 \\
\hline Sos5 & 1,000 & 5,000 & $-2,967$ & $-2,247$ & 3,590 & 2,513 \\
\hline Sos4 & 1,000 & 5,000 & $-3,252$ & $-0,671$ & 2,063 & 2,294 \\
\hline Sos3 & 1,000 & 5,000 & $-3,238$ & $-1,552$ & 3,772 & 2,552 \\
\hline Sos2 & 1,000 & 5,000 & $-3,588$ & $-2,010$ & $-4,107$ & $-1,457$ \\
\hline Sos1 & 1,000 & 5,000 & $-2,809$ & $-1,896$ & 3,228 & 0,971 \\
\hline Pri6 & 1,000 & 5,000 & $-3,116$ & $-2,511$ & 1,012 & 2,315 \\
\hline Pri5 & 1,000 & 5,000 & $-3,795$ & $-1,773$ & 3,592 & 2,524 \\
\hline Pri4 & 1,000 & 5,000 & $-3,254$ & $-1,688$ & 1,208 & 2,149 \\
\hline Pri3 & 1,000 & 5,000 & $-2,028$ & $-1,765$ & 3,700 & 2,085 \\
\hline Pri2 & 1,000 & 5,000 & $-3,258$ & $-1,724$ & 1,256 & 1,354 \\
\hline Pril & 1,000 & 5,000 & $-3,381$ & $-1,771$ & 3,818 & 0,748 \\
\hline Pro8 & 1,000 & 5,000 & $-2,932$ & $-0,944$ & 3,861 & 0,668 \\
\hline Pro7 & 1,000 & 5,000 & $-2,653$ & $-1,569$ & 3,019 & 1,080 \\
\hline Pro6 & 1,000 & 5,000 & $-2,604$ & $-2,148$ & $-3,398$ & $-1,696$ \\
\hline Pro5 & 1,000 & 5,000 & $-3,822$ & $-2,008$ & 3,479 & 2,040 \\
\hline Pro4 & 2,000 & 5,000 & $-2,814$ & $-1,942$ & $-4,073$ & $-0,310$ \\
\hline Pro3 & 1,000 & 5,000 & $-3,028$ & $-1,762$ & 3,841 & 1,587 \\
\hline Pro 2 & 1,000 & 5,000 & $-3,857$ & $-2,308$ & 3,495 & 2,109 \\
\hline Pro1 & 1,000 & 5,000 & $-2,968$ & $-1,255$ & 3,457 & 1,948 \\
\hline $\operatorname{Pg} 11$ & 1,000 & 5,000 & $-2,965$ & $-1,225$ & 3,765 & 2,259 \\
\hline $\operatorname{Pg} 10$ & 1,000 & 5,000 & $-2,953$ & $-2,123$ & 3,442 & 1,884 \\
\hline Pg9 & 1,000 & 5,000 & $-2,846$ & $-2,210$ & 3,451 & 1,922 \\
\hline Pg8 & 1,000 & 5,000 & $-2,782$ & $-1,668$ & 2,346 & 1,473 \\
\hline $\operatorname{Pg} 7$ & 1,000 & 5,000 & $-3,618$ & $-2,269$ & 4,085 & 0,361 \\
\hline Pg6 & 2,000 & 5,000 & $-3,448$ & $-0,819$ & $-3,632$ & $-2,294$ \\
\hline Pg5 & 1,000 & 5,000 & $-2,949$ & $-2,087$ & 3,356 & 1,517 \\
\hline Pg4 & 1,000 & 5,000 & $-2,800$ & $-0,823$ & 3,240 & 1,023 \\
\hline Pg3 & 1,000 & 5,000 & $-3,459$ & $-1,912$ & $-3,283$ & $-1,207$ \\
\hline Pg2 & 1,000 & 5,000 & $-3,425$ & $-1,624$ & $-3,235$ & $-1,003$ \\
\hline Pg1 & 1,000 & 5,000 & $-3,540$ & $-2,203$ & 3,047 & 2,199 \\
\hline \multicolumn{5}{|c|}{ Multivariate } & 2,509 & 0,526 \\
\hline
\end{tabular}


Journal of Honai Math, Vol. 3, No. 1, pp. 13-26, April 2020

Nur'aini \& Ruslau, Kinerja Guru Matematika Berdasarkan Persepsi dan Kompetensi Siswa SMP di Kota Merauke 